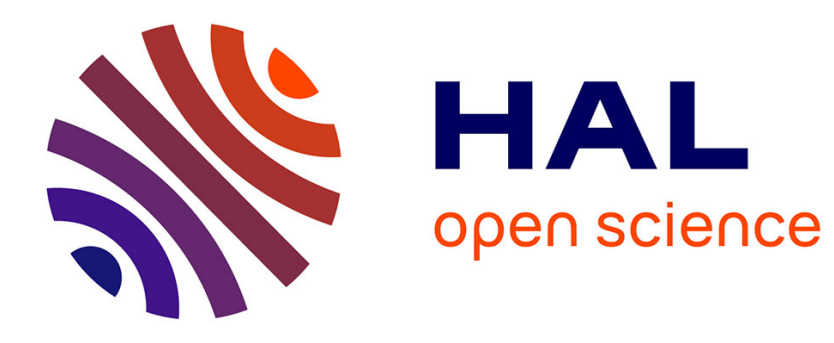

\title{
Sexual preferences for mate song in female canaries (Serinus canaria)
}

Nathalie Béguin, Gérard Leboucher, Michel Kreutzer

\section{To cite this version:}

Nathalie Béguin, Gérard Leboucher, Michel Kreutzer. Sexual preferences for mate song in female canaries (Serinus canaria). Behaviour, 1998, 135 (8), pp.1185-1196. hal-01704483

\section{HAL Id: hal-01704483 \\ https://hal.parisnanterre.fr/hal-01704483}

Submitted on 8 Feb 2018

HAL is a multi-disciplinary open access archive for the deposit and dissemination of scientific research documents, whether they are published or not. The documents may come from teaching and research institutions in France or abroad, or from public or private research centers.
L'archive ouverte pluridisciplinaire HAL, est destinée au dépôt et à la diffusion de documents scientifiques de niveau recherche, publiés ou non, émanant des établissements d'enseignement et de recherche français ou étrangers, des laboratoires publics ou privés. 
SEXUAL PREFERENCES FOR MATE SONG IN FEMALE CANARIES (SERINUS CANARIA)

running title: MATE SONG PREFERENCES IN FEMALE CANARY

NATHALIE BEGUIN, GERARD LEBOUCHER ${ }^{1)}$ \& MICHEL KREUTZER

(Equipe Oiseaux, UPRESA CNRS 7025, Laboratoire de Psychophysiologie et Ethologie, Bâtiment $\mathrm{H}$, Université de Paris X - Nanterre, 200 avenue de la république. 92001 Nanterre cedex - France)

1) Corresponding author 
3 Recent studies have shown that female passerine birds gave more sexual displays

4 for songs of their mates than for songs of other males. The present study aimed to

5 determine to what extent familiarisation with a song may account for females' song

6 preferences. Eighteen female canaries were paired with a male during a short period

7 and were later familiarised with songs. During the familiarisation period, females

8 were exposed to the sight of their previous mate while they heard the song of their

9 previous mate $(\mathrm{M})$ and while they heard the song of a non-mate (non-mate

10 reinforced, NMR). These females could also hear the song of another non-mate

11 male without sight exposure (non-mate non-reinforced, NMNR). At the end of this

12 familiarisation period, the sexual preferences of the females for these songs were

13 studied: we analysed the total number of CSD elicited by each song during the

14 whole period of sexual responsiveness. As a consequence of the method used to

15 pair the animals, 10 of the 18 females laid fertile eggs whereas 8 females laid non

16 fertile eggs. Fertile females displayed more for $M$ song than for NMR or NMNR

17 songs. Non fertile females unlike fertile females did not display preferentially for any

18 of the 3 songs and, particularly, did not show sexual preference for their previous

19 mate. These results strongly suggest that mate recognition is not a mere effect of

20 familiarisation with songs but is closely associated with previous copulatory

21 experience. When they began to display sexual responses, fertile females presented

22 a clear preference for $M$ song against NMR and NMNR songs. During this period,

23 non fertile females displayed more for NMR song than for NMNR song. In contrast,

24 before egg-laying no song preference appeared for fertile as well as for non fertile

25 females. Just before egg-laying, the females appear to be less selective towards

26 male stimuli. Modification of female sexual preferences might account for the

27 emergence of extra-pair copulations observed during the reproductive cycle in wild 28 species. 
1 Introduction

3 It has been hypothesised that bird song has three principal functions in the context of

4 sexual selection. Bird song is used (1) to repel rival males, (2) to attract and entice females and (3) to stimulate females' reproductive activity (Kroodsma \& Byers, 1991 ; Baptista \& Gaunt, 1994 ; Catchpole \& Slater, 1995). Before laying, passerine females manifest their willingness to copulate by showing a particular courtship : the copulation solicitation display (CSD). The solicitation display assay has frequently been used to measure females' preferences to playback songs (Searcy, 1992). Results of such experiments indicate that female show sexual preferences for certain categories of conspecific songs (King \& West, 1977 ; Catchpole et al., 1986) ; or for special song phrases (Vallet \& Kreutzer, 1995). It has been stated that the discrimination shown by females under these laboratory conditions was important in natural conditions because these preferences were expressed in a direct mating context (Searcy, 1992 ; O’Loghlen \& Beecher, 1997). Males whose songs are very stimulating are expected to gain high reproductive success.

Evidence that male vocalisations also play a major role in mate recognition has been reviewed by Falls (1982). Females are more responsive to recordings of their mates' vocalisations over vocalisations of non-mates (Mundinger, 1970 ; Miller, 1979 ; Wiley et al., 1991, Robertson, 1996), suggesting that females are able of recognising their mates' song. Field observations of Eens and Pixteen (1995) on female starlings tend to support this assumption.

Recently, O'Loghlen and Beecher (1997) demonstrated that female song sparrows (Melospiza melodia) gave more sexual displays and displayed more intensely for song types recorded from repertoires of their mates than for songs from other males from the local population. However, these authors pointed out that they cannot distinguish from their results whether females preferentially responded to mate song types because they recognised these types as belonging to their mates or simply because of familiarity with these song types (O'Loghlen \& Beecher, 1997).

The present study aimed to determine to what extent familiarisation with a song may account for females' song preferences. This experiment was designed taking into consideration the results of operant conditioning studies showing that the association of visual and auditory stimuli was a strong reinforcer in birds (Delsaut \& 34 Roy, 1980). Female canaries were paired with a male during three days, and were 
1 later familiarised with their mate song and with non-mate songs. During the eight-day

2 familiarisation period, females were daily exposed to the sight of their previous

3 mate ; during this exposure, they could hear the song of their previous mate and the

4 song of a non-mate. Females could also hear the song of a non-mate without sight

5 exposure. At the end of this familiarisation period, the sexual preferences of the

6 female for these songs were studied.

7 Studies in zebra finches (Taenopygia guttata) suggest that recent experience

8 is a prominent factor in female sexual choice (Collins, 1995). Taking these results

9 into account, we can hypothesise that the two songs reinforced by the sight of a male

10 will be preferred. The alternative hypothesis states that females will memorise the

11 features of their mate during the courtship period and will only prefer the song of their

12 previous mate.

13 Females were allowed to mate only during a few days, so some females failed 14 to lay fertile eggs. We analysed the results taking into account whether females laid 15 fertile or non fertile eggs. 
Methods

4 Subjects and housing

6 In this study, we used 23 female and 4 male domestic canaries (Serinus canaria). 7 The animals were chosen from a pool of 2-3 year old canaries, raised in our 8 laboratory. These animals (females and males) had previous reproductive experience but the females were never paired with each of the 4 males. Before the experiment, females and males were initially housed in aviaries during three months 11 in single-sexed groups, on a short daylight schedule (LD $8: 16$ ). Under these 12 conditions the birds show no reproductive activity. Females and males were brought 13 into breeding conditions by lengthening the photoperiod (LD $14: 10$ ). The animals 14 were housed in individual cages $(38 \times 33 \times 26 \mathrm{~cm})$, fitted with perches and nest bowls and were provided with nesting material (coconut fibbers, cotton strings). The birds were given seeds, fresh food, vitamins and water daily.

We used 4 different songs (S1, S2, S3 and S4) emitted by 4 different males (respectively M1, M2, M3 and M4) to stimulate sexual responses of the female canaries, but only two of the 4 males (M1 and M2) were paired with the females.

Experiment 1

This experiment was designed to study the effect of the 4 songs (S1, S2, S3 and S4) produced by the 4 males (M1, M2, M3 and M4) on sexual responses of 5 females, never paired with any of these 4 males.

Females were tested for song preferences according to methods previously used in our laboratory (Kreutzer \& Vallet, 1991). Female responsiveness to songs was assessed in two tests each day, one in the morning (11:00 to $12: 00)$ and one in the afternoon (15:00 to $16: 00)$. During song test sessions, sexually receptive

31 females were individually placed, in a separate room, in glass-enclosed sound 32 attenuation chambers (52 ×50 × $40 \mathrm{~cm}$ inside, $80 \times 72 \times 70 \mathrm{~cm}$ outside). Female 33 canaries were presented with 4 different playback song bouts consisting of 34 repetitions of the same song (S1, S2, S3 or S4). Each song lasted 9 s, a duration 
1 which is within the normal range for male canaries. Each song was repeated six times to build a song bout. Consecutive songs were separated by $9 \mathrm{~s}$ pauses which were chosen to allow the full development of all sexual displays. Stimuli were played back by a tape recorder $(50-14000 \mathrm{~Hz})$ connected to a speaker $(100-18000 \mathrm{~Hz})$ placed within the attenuation chamber. The degree of a female's sexual response was measured by the number of complete copulation solicitation displays (CSD). In such a complete display, the female crouched and arched her back while vibrating her wings which she held away from her body. Each complete display was scored as a unique event. Song bouts were presented at random. The females could not see any male.

12 Experiment 2

14 General

15 This experiment was divided into three distinct phases. During the first phase, 16 (reproduction), before the laying of their first clutch, females were paired with a 17 male. During the second phase, (familiarisation and song reinforcement procedure), 18 females which cared for young were daily exposed to the sight of their previous 19 mate ; during this exposure, they could hear the song of their mate and the song of a 20 non-mate. Females could also hear the song of a non-mate without sight exposure 21 (control song). During the third phase, (song test sessions), females were tested for 22 male song preferences, this stage occurred before the laying of the second clutch.

24 First phase : reproduction

25 Females were paired with a male for three days. We only used 2 different males M1 26 and M2 similar in age (2 years) and weight ( $25 \mathrm{~g}$ ), but with different songs and 27 feathers. These two males were known to have similar reproductive success in prior reproductive experiments with different females.

When a female began to place nesting material in her nest bowl, she was randomly paired with one of the two males, housed in two separate rooms. In each room, all the females - each one in her turn - were paired with the same male. This method is used by breeders to ensure the dissemination of a rare phenotype (Delille,

33 1974). During a pilot experiment, we used this method to pair the animals ; insofar as 34 females were allowed to mate only during a few days, some females failed to mate 
1 and laid non fertile eggs. In the present study, this method was used to obtain

2 females laying fertile eggs and females laying non-fertile eggs.

Ten females were paired with male M1, and eight females with male M2.

4 Females were alone to incubate and rear their young. Eight days after being laid,

5 eggs of the first clutch were candled to determine whether they were fertile or not.

6 Females which laid non fertile were given foster young when their eggs were 7 supposed to be at the onset of hatching period.

For logistic reasons, one half of females for each male was first exposed to photostimulation and the remaining half was exposed to photostimulation two months 10 later.

12 Second phase : familiarisation and song reinforcement procedure

13 This phase began when nestlings were 9 days old until they were 17 days old. Twice 14 a day each female was separated from her young during 50 minutes and subjected 15 to the familiarisation and song reinforcement procedure. The females were placed in 16 a cage within the glass-enclosed sound attenuation chambers. A tape recorder (50$1714000 \mathrm{~Hz})$ connected to a speaker $(100-18000 \mathrm{~Hz})$ diffused songs to females in the 18 sound-attenuation chamber. Females were submitted to the playback of three 19 different tape-recorded songs (presented at random and separated by one minute) : 20 the mate song, the song of a non-mate reinforced by the sight of the mate, the song 21 of a non-mate non reinforced by the sight of the mate.

The mate song $(\mathrm{M})$ was a song frequently emitted by their previous sexual partner (song S1 for male M1 or song S2 for male M2). The hearing of this song was reinforced by the sight of their mate. The mate was housed in a separate cage placed $1.5 \mathrm{~m}$ in front of the sound-attenuation chamber. Females who were mated with male M1 could see M1 when hearing song S1, females who were mated with male M2 could see M2 when hearing song S2.

The song of a non-mate reinforced by the sight of the mate (NMR) was a song emitted by a non-mate male (song S3 of male M3 and song S4 of male M4). The hearing of this song was reinforced by the sight of their mate. Females who were mated with male M1 could see M1 when hearing song S3, females who were mated with male M2 could see M2 when hearing song S4.

The song of a non-mate non reinforced by the sight of the mate (NMNR) was a control song emitted by a non-mate male. The hearing of this song was not 
1 reinforced by the sight of their mate. Females who were mated with male M1 heard

2 song S2, females who were mated with male M2 heard song S1.

3 Each song (duration 9s) was repeated six times to build a song bout ; in a song bout,

4 two consecutive songs were separated by a pause of $9 \mathrm{~s}$. The song bout was played-

5 back during $15 \mathrm{~min}$.

$7 \quad$ Third phase : song test sessions

8 At the end of the second phase, when young were 19 days old, females were tested

9 for song preferences. Previous experiments in our laboratory showed that female 10 canary began to regain sexual activity when their young were 20 days old (Nagle et 11 al., 1993). Female responsiveness to songs was assessed in two song test sessions 12 each day, one in the morning (11:00 to $12: 00)$ and one in the afternoon (15:00 to $1316: 00$ ), as previously described (see Experiment 1). During song test sessions, 14 females were temporarily separated from their young ; individual cages were placed, 15 in a separate room, in sound attenuation chambers. Female canaries were presented with M (S1 or S2), NMR (S3 or S4) and NMNR (S1 or S2) playback songs.

18 Data analysis

20 Experiment 1

21 Female preferences were analysed using the CSD displayed during song test sessions. To estimate female preferences we analysed the total number of CSD

23 elicited by each song during the whole period of sexual responsiveness (Total 24 number of CSD). After log transformation of data, parametric statistics were used 25 (Winer, 1971). One way ANOVA for repeated measures, followed by post-hoc 26 multiple comparisons tests (Newman-Keuls) was used to analyse the total number of 27 CSD for the 3 songs.

Experiment 2

30 Female preferences were analysed using the CSD displayed during song test 31 sessions. Two variables were taken into account to analyse data on CSD : (a) the 3 32 different songs (M, NMR, NMNR) and (b) the fertility of females (fertile, non fertile). 33 To estimate female preferences we analysed the total number of CSD elicited by 34 each song during the whole period of sexual responsiveness (Total number of CSD). 
1 Moreover, we analysed female preferences taking into account the development of 2 female responsiveness. The number of CSD elicited during the first 2 days of sexual 3 responsiveness (CSD at the beginning of sexual responsiveness) and during the two 4 days preceding the formation of the first egg of the second clutch (CSD before egg5 laying) were taken into account.

6 After log transformation of data, parametric statistics were used. Two-way 7 ANOVA for repeated measures, followed by post-hoc multiple comparisons tests 8 (Newman-Keuls) was used to analyse the number of CSD for the 3 songs. Moreover, 9 t-tests were used to compare 2 independent measures. 


\section{Results}

4 Experiment 1

The one-way ANOVA for repeated measures revealed no significant effect of songs for the total number of $\operatorname{CSD}(d f=3, F=0.29, p=0.83)$. The five females did not appear to prefer any of the 4 songs (Fig. 1).

\section{Experiment 2}

13 As a consequence of the method used to pair the animals, 10 of the 18 females laid

14 fertile eggs whereas 8 females laid non fertile eggs. Six females paired with M1 and 154 females paired with M2 laid fertile eggs ; 4 females paired with M1 and 4 females paired with M2 laid non fertile eggs. Eight of the 10 fertile females had been paired at least one day before laying the first egg of the clutch whereas only 3 of the 8 non fertile females had been paired before the first egg. The remaining females ( 2 fertile and 5 non fertile females) had been paired the day they laid the first egg.

Fertile females laid $4.5 \pm 0.22$ eggs and non fertile females laid $4.38+0.32$ eggs (t-test, $p=0.75)$. Females raised one or two young $(1.6 \pm 0.22$ for fertile females vs. $1.13 \pm 0.13$ for non fertile females ; t-test, $p=0.1$ ).

During the third phase of the experiment (song test sessions), females began to display CSD about seven days before laying the first egg of the second clutch (7.11 \pm 1 days before the first egg). The end of sexual responsiveness occurred just after the laying of the first egg $(0.33 \pm 0.51$ day after the first egg).

The two-way ANOVA for repeated measures revealed a significant effect of songs and a significant interaction between songs and fertility factors for the total number of CSD and for the number of CSD at the beginning of sexual responsiveness (Table 1). These results indicate that the effect of different songs depended on whether females laid fertile or non fertile eggs. Cell comparisons were used instead of main effect analysis. For the total number of CSD and for the CSD at

33 the beginning of sexual responsiveness, fertile females displayed more for $M$ song 34 than for NMR or NMNR songs (Fig. 2 A \& B). For non fertile females no difference 
1 was found between songs when considering the total number of CSD ; in contrast 2 analysis of the CSD at the beginning of sexual responsiveness indicates that non 3 fertile female gave more CSD for NMR than for NMNR songs (Fig. 2 B). Moreover, 4 non fertile females displayed more for NMR than fertile females when considering 5 the total number of CSD (Newman-Keuls, $p<0.05$ ) or when considering the CSD at 6 the beginning of sexual responsiveness (Newman-Keuls, $p<0.01$ ).

7 The two-way ANOVA for repeated measures revealed no significant effects of 8 songs or fertility and no significant interaction between songs and fertility factors for 9 the CSD before egg-laying (Table 1). 
Discussion

$4 \quad$ Pairing and fertility of the females

6 In the second experiment, ten of the 18 females laid fertile eggs whereas 8 females

7 laid non fertile eggs. Insofar as females had previous reproductive experience and

8 laid fertile eggs in previous reproductive cycles, we can assume that non fertile

9 females failed to copulate or, at least, failed to copulate repeatedly with their sexual

10 partner. Several studies have pointed out that multiple mating with the same male 11 could ensure fertilisation (Martin et al,. 1974 ; Birkhead, 1988 ; Møller \& Birkhead, 121992 ; Whittingham et al., 1994). The timing of pairing may account, partly, for this 13 result. Most fertile females (8 on 10) were paired at least one day before laying their 14 first egg, in contrast, most of non fertile females (5 on 8) were paired the day they 15 laid their first egg. Paired animals were not systematically observed; however, empirical observations carried out during the present experiment or during a pilot

17 experiment indicated that copulation did not occur during the first few hours of pairing 18 even if females were fully receptive : a familiarisation period between the two sexual 19 partners seemed to be necessary. In a previous study (Leboucher et al,. 1994) we 20 observed that C.S.D to tape-recorded songs were displayed mainly between nest21 building and egg-laying and disappeared progressively thereafter ; moreover during 22 the third phase of the second experiment (song test sessions) the end of sexual 23 responsiveness occurred just after the laying of the first egg of the second clutch $24(0.33 \pm 0.51$ days after the first egg). It is likely that during the first phase of the 25 experiment, the majority of the non fertile females were belatedly paired and 26 consequently rejected most copulation attempts.

28 Total number of CSD displayed by fertile and non fertile females

30 During the first experiment, females without previous sexual experience with the 31 males which emitted the songs failed to display song preferences (Fig . 1); this 32 result indicates that the four songs used in the two experiments (S1, S2, S3 and S4) 33 had the same sexual value. In contrast, during the second experiment, fertile females 34 displayed more for M song (S1 or S2) than for NMR (S3 or S4) or NMNR (S1 or S2) 
1 songs (Fig. 2 A). Mate recognition on the basis of song is widespread in bird species

2 (Mundinger, 1970 ; Miller, 1979 ; Wiley et al., 1991 ; Robertson, 1996). As previously

3 stated (see Introduction), O'Loghlen \& Beecher (1997) demonstrated that female

4 song sparrows (Melospiza melodia) were more readily stimulated to perform sexual

5 displays when presented with song types from repertoires of their mates than songs

6 from other males in the local population. These authors failed to distinguish from

7 their results whether females preferentially responded to mate song types because

8 they recognised these types as belonging to their mates or simply because of

9 familiarity with these song types (O'Loghlen and Beecher ; 1997). The present study

10 clearly shows that mate recognition is not a mere effect of familiarisation with songs :

11 fertile female displayed more for the mate song than for the two non mate songs

12 despite one of the non-mate songs was reinforced by the sight of the mate like the

13 mate song during the recent period of familiarisation.

14 Non fertile females unlike fertile females did not display preferentially for any 15 of the 3 songs (Fig. 2 A), and particularly, did not show sexual preference for their 16 previous mate. In our experiment, females with non fertile eggs were given foster 17 young to adopt. Consequently, it is unlikely that the lack of egg fertilisation could be a 18 salient cue used to weight mate versus non-mate songs. This result strongly suggest 19 that mate song preference is closely associated with previous copulatory experience.

20 As far as we know, similar results have not yet been reported. However, previous 21 studies showed that in female birds, the divorce rate was negatively correlated with 22 reproductive success during the previous breeding (Lindén, 1991; Choudhury, 23 1995).

25 Development of song preferences in fertile and non fertile females

27 When they began to display sexual responses, fertile females presented a clear 28 preference for $\mathrm{M}$ song against NMR and NMNR songs (Fig. $2 \mathrm{~B}$ ). During this period, non fertile females tended to display more for $M$ and NMR songs than for NMNR song (number of CSD are respectively : $3.38 \pm 1.85,4.00 \pm 1.71$ and $1.5 \pm 0.95$ )

31 (Fig. 2 B). This result suggest that the female choice was affected by their recent 32 experience (Collins, 1995), namely, the familiarisation and reinforcement period; 33 however the difference between $M$ and NMNR songs did not reach statistical 34 significance $(p=0.1)$. 
In contrast, before egg-laying no song preference appeared for fertile as well 2 as for non fertile females (Table 1, Fig. 2 C). So, just before egg-laying, females seemed to be less selective towards male stimuli. In mammals, T-maze experiments indicated that gilts were less selective towards male stimuli when sexual motivation was high, during the fertile and receptive period, and more selective before and after the receptive period (de Jonge et al., 1994). As far as we know, variation in sexual selectivity during the reproductive cycle of female birds have not been yet evidenced. The causal bases for perceptive or cognitive variations during the course of the reproductive cycle are still unknown. However, neurophysiological studies of

10 Brenowitz (1991) on female canaries indicated that the forebrain nucleus HVC,

11 played a role in specific song recognition. More recent studies, in our laboratory (Del

12 Negro et al., 1998) showed that chemical lesion of the HVC reduced discrimination

13 between two conspecific songs in female canaries. Estrogen receptors were found in

14 the region of the HVC in male as well as in female canaries (Fusani et al., 1996 ;

15 Gahr et al., 1987). So, it is not unlikely that the variations in estradiol concentrations during the reproductive cycle mediate female selectivity through hormonal effects on 17 the HVC. (Breutel et al., 1997)

18 Field studies indicate that a non negligible proportion of young in broods of 19 female birds are the outcome of extra-pair copulations (Wagner, 1991; Dunn \& 20 Lifjeld, 1994 ; Kempenaers et al., 1995 ; Whittingham \& Lifjeld, 1995). These extra21 pair copulations could be an important component of the reproductive success of 22 female (Birkhead \& Møller ,1992). There are also increasing evidence that females 23 initiate, not just resist or accept extra-pair courtship (Sheldon 1994 ; Gray, 1996). We 24 have no information about the distribution of extra-pair copulations during the 25 reproductive cycle in female canaries ; particularly, we don't know if females solicit 26 for extra-pair copulations just before egg-laying when their sexual selectivity is low. In 27 other species, like red-winged blackbirds (Agelaius phoeniceus), extra-pairs 28 copulations reach a peak two days before egg-laying (Gray, 1996). Likewise, female chaffinches (Fringilla coelebs) solicit for extra-pair copulations at a particularly high rate in the days immediately before laying (Sheldon, 1994). Modification of female sexual preferences may account for the emergence of extra-pair copulations observed during the reproductive cycle in wild species. 


\section{References}

3 Baptista, L.F. \& Gaunt, S.L.L. (1994). Advances in studies of avian sound communication. - Condor 96, p. 817-830.

Birkhead, T. R. (1988). Behavioural aspects of sperm competition in birds. - Adv. Stud. Behav. 18, p 35-72.

Birkhead, T.R. \& Møller, A.P. (1992). Sperm competition in birds : Evolutionary Causes and Consequences. - Academic Press, London.

Brenowitz, E.A. (1991). Altered perception of species-specific song by female birds after lesions of a forebrain nucleus. - Science 251, p 303-305.

11 Breutel, G., Del Negro, C. \& Gahr, M. (1997). Changes in the motivation to sing and to react to song correlate with neurophysiological changes in the song control system of birds. - Advances in Ethology 32, p. 20.

Catchpole, C.K. \& Slater, P.J.B. (1995) Bird song: biological themes and variations. - Cambridge Univ. Press, Cambridge.

de Jonge, F.H., Mekking, P., Abbott, K. \& Wiepkema, P.R. (1994). Proceptive and

- - Leisler, B. \& Dittami, J. (1986) Sexual differences in the responses of captive great reed warblers (Acrocephalus arundinaceus) to variation in song structure and repertoire size. - Ethology 73, p 69-77.

Choudhury, S. (1995). Divorce in birds: a review of the hypotheses. - Anim. Behav. 50, p 412-429.

Collins, S.A. (1995). The effect of recent experience on female choice in zebra finches. - Anim. Behav. 49, p 479-486. receptive aspects of oestrus behaviour in gilts. - Behavioural Processes $31, p$ 157-166.

Del Negro, C., Gahr, M., Leboucher, G. \& Kreutzer M. (1998). The selectivity of sexual responses to song displays : effects of partial chemical lesion on the HVC in female canaries. - Behav. Brain Res. in press.

Delille, A. (1974). ABC pratique de l'éleveur de canaris couleurs. - Editions du Sapin vert.

Delsaut, M. \& Roy, J.C. (1980). Auditory and visual stimuli as reinforcers among lovebirds (Agapornis roseicollis). - Behavioral and Neural Biology 28, p 319334. 
1 Dunn, P. O. \& Lifjeld, J. T. (1994). Can extra-pair copulations be used to predict extra-pair paternity in birds ? - Anim. Behav. 47, p 983-985.

Eens, M. \& Pinxten, R. (1995). Inter-sexual conflicts over copulations in the European starling: evidence for the female mate-guarding hypothesis. Behav. Ecol. Sociobiol. 36, p 71-81.

Falls, J. B. (1982). Individual recognition by sounds in birds. - In: Acoustic communication in birds, vol. 2 (D. E. Kroodsma \& E.H. Miller, eds), p. 237-278. Academic Press, New York.

Fusani, L., Metzdorf, R., Wozniak, A., Hutchison, J.B. Gahr, M. (1996). Estrogendependence of vocal patterns in canaries. - Italian Journal of Anatomy and Embryology 101 (suppl.1), p.124.

Gahr, M., Flügge, G. \& Güttinger, H.R. (1987). Immunocytochemical localization of estrogen-binding neurons in the songbird brain. - Brain Research 402, p. 173177.

Gray, E. M. (1996). Female control of offspring paternity in a western population of red-winged blackbirds (Agelaius phoeniceus). - Behav. Ecol. Sociobiol. 38, p 267-278.

Kempenaers, B., Verheyen, G. R. \& Dhondt, A. A. (1995). Mate guarding and copulation behaviour in monogamous and polygynous blue tits: do males follow a best-of-a-bad-job strategy ? - Behav. Ecol. Sociobiol. 36, p 33-42.

King, A.P. \& West, M.J. (1977). Species identification in the North American cowbird : appropriate responses to abnormal song. - Science 195, p 10021004.

Kreutzer,M. \& Vallet,E. (1991). Differences in the responses of captive female canaries to variation in conspecific and heterospecific songs. - Behaviour 117, p. 106-116.

Kroodsma, D.E. \& Byers, B.E. (1991). The function(s) of bird song. - Amer. Zool. 31 , p. 318-328.

Leboucher, G., Kreutzer, M. \& Dittami, J. (1994). Copulation-solicitation displays in female canaries (Serinus canaria): are œstradiol implants necessary? Ethology 97, p. 190-197.

Lindén, M. (1991). Divorce in great tits - chance or choice ? An experimental approach. - Am. Nat. 138, p 1039-1048. 
Martin, P. A., Reimers, T. J., Lodge, J. R. \& Dzuik, P. J. (1974). The effect of ratios and numbers of spermatozoa mixed from two males on the proportion of offspring. - J. Reprod. Fert. 39, p 251-258.

Miller, D. B. (1979). The acoustic basis of mate recognition by female zebra finches (Taenopygia guttata). - Anim. Behav. 27, p 376-380.

Mundinger, P. C. (1970). Vocal imitation and individual recognition in finch calls. Science 168, p 480-482.

Møller, A. P., Birkhead, T. R. (1992). A pairwise comparative method as illustrated by copulation frequency in birds. - Am. Nat. 139, p 644-656.

Nagle, L., Kreutzer, M.L. \& Vallet, E.M. (1993). Obtaining copulation solicitation displays in female canaries without estradiol implants. - Experientia. 49, p. 1022-1023.

O' Loghlen, A.L. \& Beecher, M.D. (1997). Sexual preferences for mate song types in female song sparrows. - Anim. Behav. 53, p 835-841.

Robertson, B.C. (1996). Vocal mate recognition in a monogamous, flock-forming bird, the silvereye, (Zosterops lateralis). - Anim. Behav. 51, p 303-311.

Searcy, W.A. (1992). Measuring responses of female birds to male song. - $-\ln$ : Playback and studies of animal communication (McGregor P.K., ed). Plenum Press, New York. p. 175-189.

Sheldon, B. C. (1994). Sperm competition in the chaffinch : the role of the female. - Anim. Behav. 47, p 163-173.

Vallet, E. \& Kreutzer, M. (1995). Female canaries are sexually responsive to special song phrases. - Anim. Behav. 49, p 1603-1610.

Wagner, R. H. (1991). Evidence that female razorbills control extra-pair copulations. - Behaviour 118, p 157-169.

Whittingham, L. A., Dunn, P. O. \& Robertson, R. J. (1994). Do female tree swallows guard their mates by copulating frequently ? - Anim. Behav. 47, p 994-997.

Wiley, R. H., Hatchwell, B. J. \& Davies, N. B. (1991). Recognition of individual males' songs by female dunnocks : a mechanism increasing the number of copulatory partners and reproductive success. - Ethology 88, p 145-153.

Winer, B.J. (1971). Statistical principals in experimental design. - McGraw-Hill, London. 
1 Fig. 1. Effects of 4 tape-recorded songs, S1, S2, S3, S4 on the total number of CSD 2 showed by females $(N=5)$ never paired with any of the 4 males which emitted these 3 songs. Statistical analysis: one-way ANOVA for repeated measures ( $\mathrm{df}=3$, $4 \quad F=0.29, p=0.83$ ).

5

6

7 Fig. 2 Effect of the mate song (M), the song of a non-mate reinforced by the sight of 8 the mate (NMR) the song of a non-mate non reinforced by the sight of the mate 9 (NMNR) on (A) the total number of CSD, (B) the number of CSD at the beginning of 10 sexual responsiveness and $(C)$ the number of CSD before egg-laying, of fertile $11(\mathrm{~N}=10)$ and non fertile females $(\mathrm{N}=8)$. Statistical analyses : two-way ANOVA for 12 repeated measures, see Table 1; post hoc analyses, Newman-Keuls tests, a: 13 indicates a significant difference with $M$ song, $b$ : indicates a significant difference 14 with NMR song, ${ }^{*}: p<0.05$ and ${ }^{* *}: p<0.01$. 


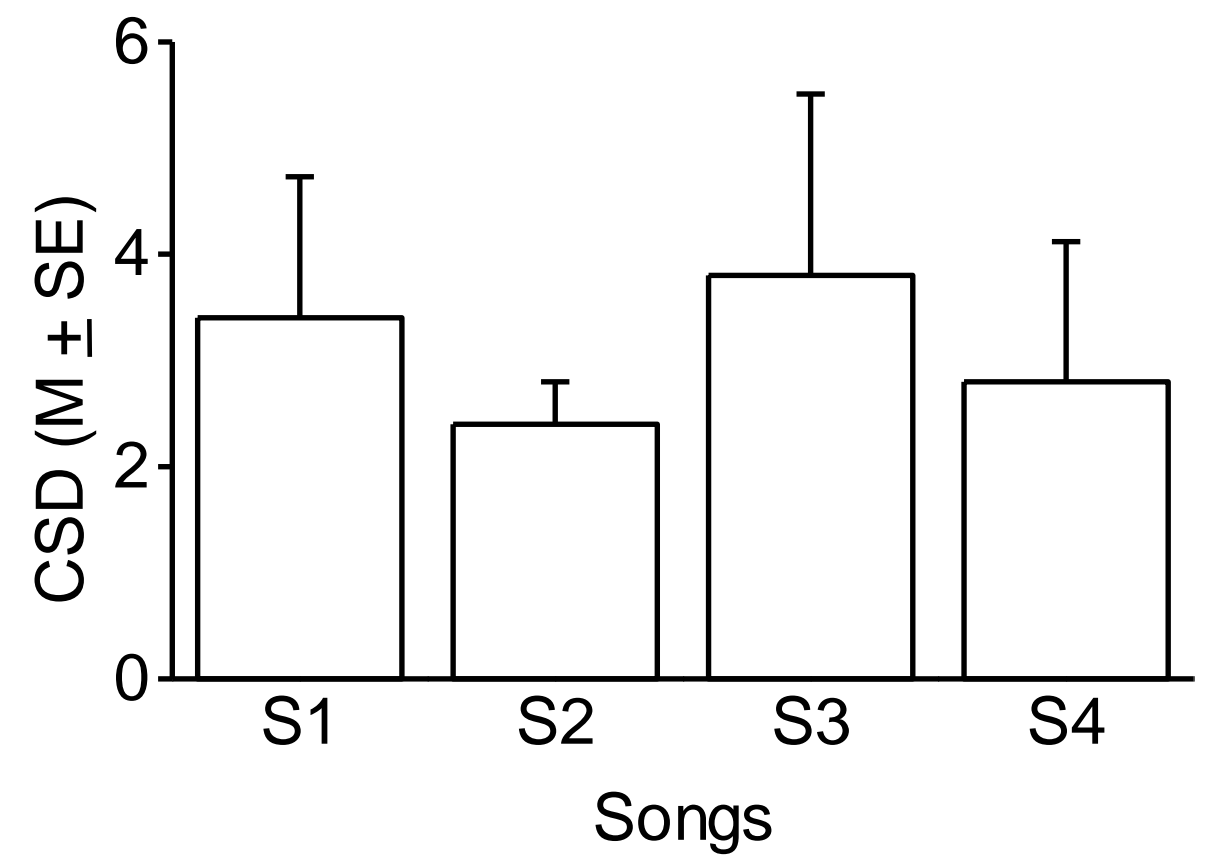




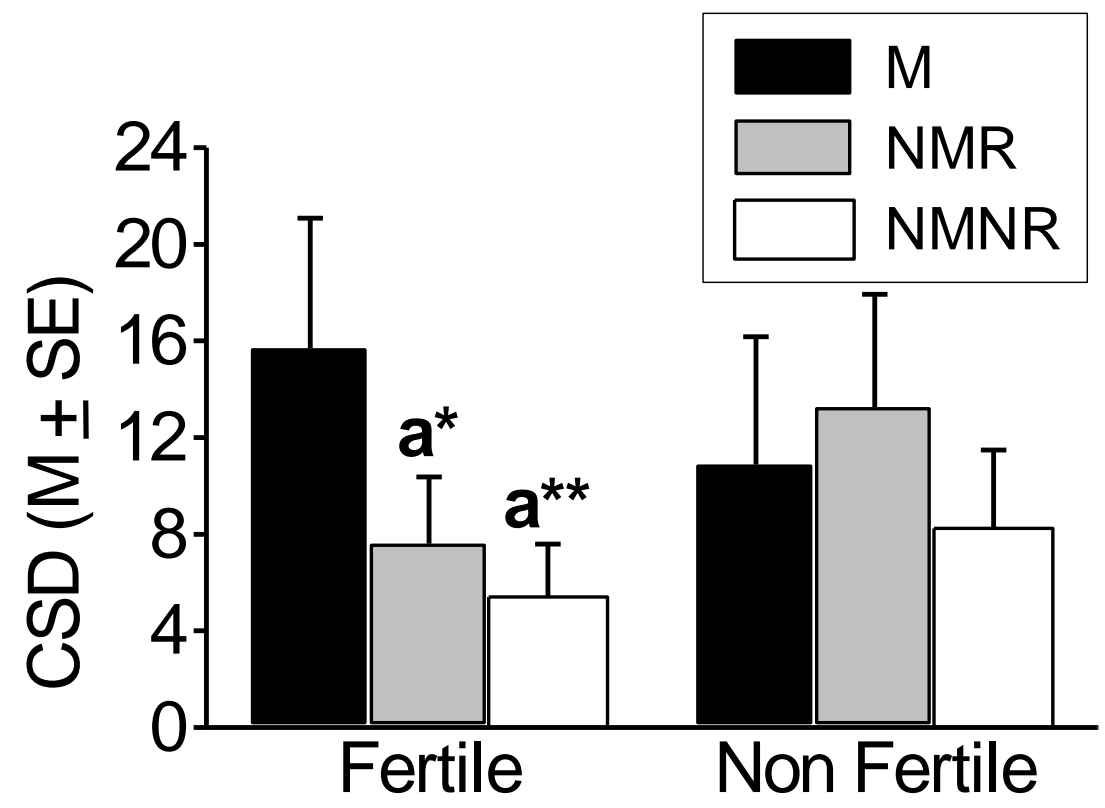

A

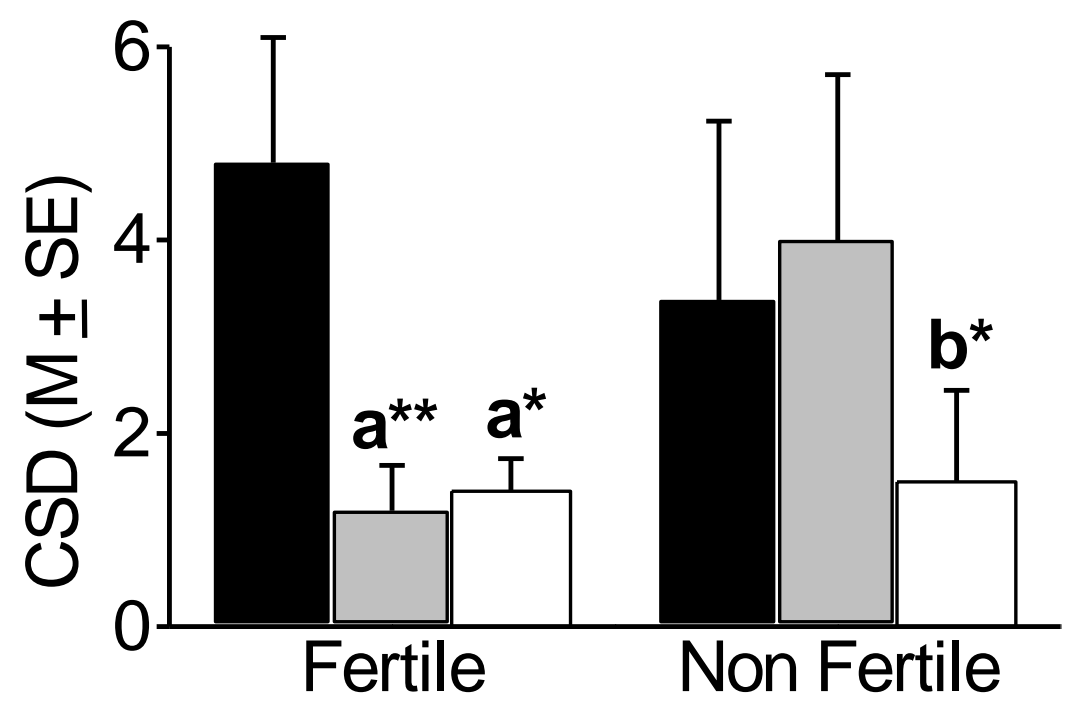

B

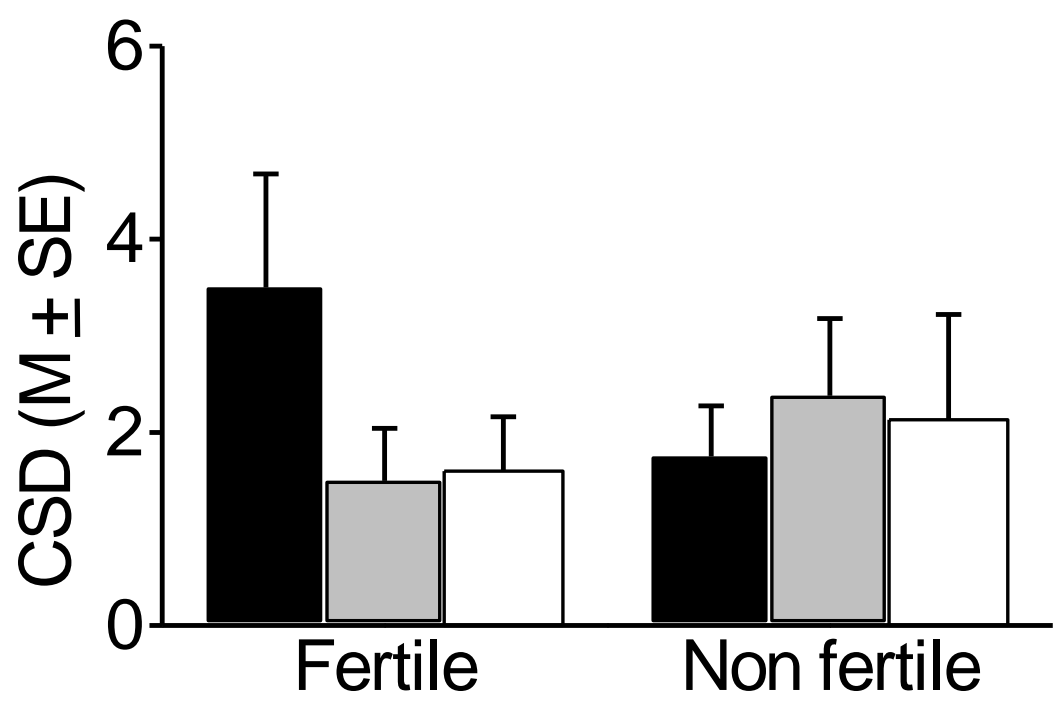

C 
TABLE 1. Experiment 2 : results of the two-way ANOVA for repeated measures $(d f=2,1,2)$.

\begin{tabular}{|c|c|c|c|c|c|c|}
\hline & \multicolumn{2}{|c|}{$\begin{array}{l}\text { Songs (Mate, Non Mate } \\
\text { Reinforced, Non Mate Non } \\
\text { Reinforced) }\end{array}$} & \multicolumn{2}{|c|}{ Fertility (Fertile, Non Fertile) } & \multicolumn{2}{|c|}{ Interaction } \\
\hline & $f$ & $\mathrm{p}$ & $f$ & $\bar{p}$ & $f$ & $\bar{p}$ \\
\hline Total number of CSD & 5.84 & 0.007 & 0.28 & 0.60 & 4.63 & 0.017 \\
\hline $\begin{array}{l}\text { CSD at the beginning of sexual } \\
\text { responsiveness }\end{array}$ & 7.48 & 0.002 & 0.02 & 0.90 & 7.49 & 0.002 \\
\hline CSD before egg-laying & 1.23 & 0.30 & 0.01 & 0.92 & 1.93 & 0.16 \\
\hline
\end{tabular}

